\title{
Direct high-precision U-Pb geochronology of the end-Cretaceous extinction and calibration of Paleocene astronomical timescales
}

By

5 William C. Clyde ${ }^{\mathrm{a}}$, Jahandar Ramezani ${ }^{\mathrm{b}}$, Kirk R. Johnson ${ }^{\mathrm{c}}$, Samuel A. Bowring , Matthew M. Jones ${ }^{\mathrm{a}, \mathrm{d}}$

7 a Department of Earth Sciences, University of New Hampshire, 56 College Rd., Durham, NH 03824,

$8 \quad$ will.clyde@unh.edu

$9 \quad$ Department of Earth, Atmospheric and Planetary Sciences, Massachusetts Institute of Technology, 77

10 Massachusetts Avenue, Cambridge, MA 02139, ramezani@mit.edu

c National Museum of Natural History, Smithsonian Institution, MRC 106, P.O. Box 37012, Washington DC, 20013,johnsonkr@si.edu

dDepartment of Earth and Planetary Sciences, Northwestern University, Technological Institute, 2145 Sheridan Road, Evanston, IL 60208, matthewjones2012@u.northwestern.edu

Keywords: K-Pg Boundary; Geochronology; Magnetostratigraphy; Astrochronology; Paleocene; 28 


\begin{abstract}
The Cretaceous-Paleogene (K-Pg) boundary is the best known and most widely recognized global time horizon in Earth history and coincides with one of the two largest known mass extinctions. We present a series of new high-precision Uranium-Lead (U$\mathrm{Pb}$ ) age determinations by the chemical abrasion isotope dilution thermal ionization mass spectrometry (CA-ID-TIMS) method from volcanic ash deposits within a tightly constrained magnetobiostratigraphic framework across the K-Pg boundary in the Denver Basin, Colorado, USA. This new timeline provides a precise interpolated absolute age for the K-Pg boundary of $66.021 \pm 0.024 / 0.039 / 0.081 \mathrm{Ma}$, constrains the ages of magnetic polarity Chrons C28 to C30, and offers a direct and independent test of early Paleogene astronomical and ${ }^{40} \mathrm{Ar} /{ }^{39} \mathrm{Ar}$ based timescales. Temporal calibration of paleontological and palynological data from the same deposits show that the interval between the extinction of the dinosaurs and the appearance of earliest Cenozoic mammals in the Denver Basin lasted $\sim 228 \mathrm{ky}$ (and no more than $570 \mathrm{ky}$ ) and the 'fern spike' lasted $\sim 1 \mathrm{ky}$ (and no more than $71 \mathrm{ky}$ ) after the K-Pg boundary layer was deposited, indicating rapid rates of biotic extinction and initial recovery in the Denver Basin during this event.
\end{abstract}

\title{
1. Introduction
}

The geological timescale provides the framework for interpreting Earth history. Major

subdivisions of the timescale correspond to mass extinctions such as the K-Pg boundary, one of the two is critical for examining rates of geological and biological processes. Recent advances in radioisotope geochronology and astrochronology have led to proposed timescale calibrations of unprecedented precision. Astrochronological models are based on the interpretation of sedimentary cyclicity as being driven by astronomical forcing of climate. However, because of uncertainties associated with the chaotic nature of planetary dynamics, astronomical timescales older than $\sim 50 \mathrm{Ma}$ are not considered robust unless tested by independent geochronological methods (Laskar et al., 2011a). Such tests are often difficult because astrochronologies are typically derived from deep sea records where dateable volcanic deposits are rare. Here we use high-precision U-Pb geochronology (CA-ID-TIMS technique) of intercalated ash beds to date the K-Pg boundary and surrounding magnetic polarity reversals in fossiliferous continental rocks from the Denver Basin of Colorado (USA) to calibrate the early Paleogene astronomical timescale and precisely constrain the tempo of extinction and recovery. 
The Geomagnetic Polarity Timescale (GPTS) is commonly used to sequence events in geological

time yet was traditionally calibrated in absolute time by only a handful of ${ }^{40} \mathrm{Ar} /{ }^{39} \mathrm{Ar}$ age determinations from widely separated geographic locations and had relatively large intercalibration uncertainties (e.g. Cande and Kent, 1995, 1992). The most recent GPTS calibrations (GTS2004 - Gradstein et al., 2004 and GTS 2012 - Gradstein et al., 2012) have capitalized on advances in geochronology and used a numerical calibration that integrates both radioisotopic and astrochronological constraints. However, stand-alone astronomical timescales prior to the Neogene remain uncertain due to the chaotic nature of planetary interactions (Hinnov and Hilgen, 2012) and varied interpretations of local cyclostratigraphic data (e.g. Dinarès-Turell et al., 2014). Therefore, these timescales must be tested and refined using independent geochronological methods that can attain higher resolution than the shortest astronomical frequency used. Uranium-lead zircon geochronology by the ID-TIMS method is particularly suitable for high-resolution calibration of geologic time because it takes advantage of two independent radioactive decay schemes with precisely measured decay constants (e.g. Bowring et al., 2006). In addition, the accuracy of U-Pb dates does not rely on the age of mineral standards and the effects of open system behavior in zircon can be readily detected and mitigated. By directly calibrating individual globally correlated stratigraphic events (e.g. K-Pg boundary, Chron boundaries) using multiple high-resolution U-Pb ages in a single integrated stratigraphic framework, we are able to achieve higher precision than most previous studies without reliance on models of sea-floor spreading or long-term sedimentation rates.

\section{Geological Background and Sampling Sites}

The Denver Basin is an ideal place for developing a high-resolution timescale for the latest Cretaceous and early Paleogene because it has a thick sequence of fossiliferous synorogenic sediments that are well suited for paleomagnetic analysis and include abundant interbedded volcanic ash deposits, all of which are accessible via correlative core and outcrop records (Figure 1). All sampling for this study was carried out in the upper Cretaceous-Paleocene D1 sequence. The D1 sequence is an unconformity bounded package of fluvial/paludal sandstone, mudstone, and lignite beds, underlain by the Laramie 
Formation and overlain by the lower Eocene D2 sequence (Raynolds, 2002). The K-Pg boundary itself is exceptionally well preserved in the D1 sequence, with evidence of bolide impact and biotic change that includes an iridium and osmium anomaly (Barclay, 2003; Zaiss et al., 2014), shocked quartz (Barclay, 2003), extinctions of dinosaurs and plants (Nichols and Fleming, 2002; Carpenter and Young, 2002; Barclay, 2003), and subsequent biotic recovery (e.g. fern "spike" and mammal diversification; Nichols and Fleming, 2002; Dahlberg et al., 2016). However, testing of extinction and recovery models in the basin has been hindered by a lack of detailed high-resolution chronologies across the boundary interval. The multiple interbedded volcanic ash beds across the K-Pg boundary in the D1 sequence studied here allow calibration of this interval with unprecedented levels of precision and accuracy. One core (Kiowa core) and four surface stratigraphic sections (Haas Ranch, Easy-to-Reach, My Lucky Number, and West Bijou Creek) were sampled for this study (Figure 1). The $688 \mathrm{~m}$ (2256 ft) Kiowa core $\left(39.35242^{\circ} \mathrm{N}, 104.46642^{\circ} \mathrm{W}\right)$ was drilled in 1999 and resulted in $93 \%$ core recovery through the Pierre, Fox Hills, Laramie, D1 and D2 lithological units (Raynolds et al., 2001). The surface sections lie along the western slope of the adjacent West Bijou Creek Escarpment, which cuts progressively down section toward the north (Figures $1 \& 2$ ). Many fossil localities have been tied to these surface sections and provide an important biostratigraphic framework that cannot otherwise be achieved in the core (Johnson et al., 2003).

\section{Methods}

3.1 Paleomagnetic Methods - Twenty-three oriented paleomagnetic samples were collected from the Kiowa core at the USGS Core Repository and subsequently cut into $8 \mathrm{~cm}^{3}$ cubes at the University of New Hampshire (UNH). Two of the samples were large enough to create separate sub-samples which allowed us to perform duplicate analyses at these two levels. Sampling levels in the core were selectively chosen to increase the magnetostratigraphic resolution achieved by Hicks et al. (2003) and thus were concentrated near previously identified polarity reversal boundaries. Sampling was limited to horizons 
112 with mudstone and fine sandstone lithologies appropriate for paleomagnetic analysis. Detailed

113 lithological logs of the Kiowa core can be found in Raynolds et al., 2001.

114 In addition to resampling the Kiowa core, three of the surface sections were sampled to develop a

115 parallel polarity record from outcrops that can be correlated to the core. Three or more oriented hand

116 samples were collected from (1) 10 sites within the My Lucky Number section, (2) 8 sites within the

117 Easy-to-Reach section, and (3) 12 sites within the Haas Ranch section (Figure 1). The West Bijou Creek

118 section was previously analyzed by Hicks et al. (2003). Like in the Kiowa core, samples were taken from

119 appropriate lithologies (mudstone to fine sandstone) and cut into $8 \mathrm{~cm}^{3}$ cubes for further analysis. In some

120 cases, poor exposure or the existence of large channel sandstones limited the sampling resolution that

121 could be achieved in the surface exposures. Lithological information for samples from these surface

122 sections can be found in Table S2.

All paleomagnetic analyses were conducted in the paleomagnetics laboratory at UNH with an

124 HSM2 SQUID cryogenic magnetometer, a Molspin tumbling alternating-field demagnetizer, and an ASC

125 Model TD48 SC thermal demagnetizer. Sample demagnetization protocol was based on the prior results

126 of Hicks et al. (2003) and involved step-wise alternating field demagnetization in $2 \mathrm{mT}$ steps up to 25

$127 \mathrm{mT}$ and then $5 \mathrm{mT}$ steps thereafter until the natural remanent magnetization (NRM) intensity dipped

128 below the sensitivity of the magnetometer or until the NRM no longer decreased in intensity. Several

129 samples that were not completely demagnetized by this AF protocol were further demagnetized using

130 step-wise thermal demagnetization to eliminate any remaining NRM and isolate any high coercivity

131 components. After these demagnetization procedures, samples with NRM directions exhibiting a

132 relatively linear decay to the origin were characterized by least squares analysis (Kirschvink, 1980).

133 Those samples that exhibit initial decay followed by strong clustering of vector end points, but no linear

134 decay to the origin, were calculated using a Fisher mean. In some samples, the overlapping unblocking

135 spectra of the magnetic components obscured any linear demagnetization trends, and we used the

136 progression of remanence directions along a great circle path from the overprinting direction to a

137 characteristic direction to describe the Characteristic Remanent Magnetization (ChRM). In a few cases, 
samples exhibited unstable demagnetization behavior and could not be used for purposes of polarity

139 determination. For sites that included samples characterized by a great circle, the methods of McFadden

140 and McElhinny (1988) were used to calculate a mean. Because the Kiowa core was unoriented with

141 respect to azimuth, only the inclination of the characteristic remananet magnetization is used for

142 determining polarity in those samples, however both declination and inclination are used for samples

143 from surface sites.

3.2 U-Pb Geochronology Methods - Zircons were separated from interbedded tuffs from 5

146 samples from the Kiowa core and 9 samples from the outcrops, spanning the Maastrichtian (Chron C29r)

147 to the Early Paleocene (Chron C28n). Heavy mineral separation from bentonitic tuffs was achieved by an

148 ultrasonic device (Hoke et al., 2014), followed by magnetic and high-density liquid separation; individual

149 zircons were hand selected for analysis under a binocular microscope based on grain morphology and

150 clarity. A total of 159 zircons were analyzed by the U-Pb isotope dilution thermal-ionization mass

151 spectrometry (ID-TIMS) technique following the detailed procedures described in Ramezani et al. (2011).

152 All zircons were pre-treated by a chemical abrasion (CA-TIMS) method modified after Mattinson (2005)

153 to mitigate the effects of radiation-induced $\mathrm{Pb}$ loss, and spiked with the EARTHTIME ET535 mixed

$154{ }^{205} \mathrm{~Pb}_{-}{ }^{233} \mathrm{U}-{ }^{235} \mathrm{U}$ tracer (Condon et al., 2015; McLean et al., 2015) prior to dissolution and analysis.

155 Complete $\mathrm{U}-\mathrm{Pb}$ data appear in Table $\mathrm{S} 1$.

156 Many of the Denver Basin tuff samples contain xenocrystic zircon from older sources (see

157 below). Sample dates representing the best estimate for the depositional age are thus derived from

158 weighted mean ${ }^{206} \mathrm{~Pb} /{ }^{238} \mathrm{U}$ date of a statistically coherent cluster of the youngest zircon analyses from each

159 sample, provided that there are more than 3 precise analyses to form a cluster. All calculated date

160 uncertainties are reported at the $95 \%$ confidence level $(2 \sigma)$ and follow the notation $\pm \mathrm{X} / \mathrm{Y} / \mathrm{Z}$ Ma (Table 1),

161 where $\mathrm{X}$ is the internal (analytical) uncertainty in the absence of all external errors, $\mathrm{Y}$ incorporates the U-

$162 \mathrm{~Pb}$ tracer calibration error and $\mathrm{Z}$ includes the latter as well as the $\mathrm{U}$ decay constant errors. Complete

163 uncertainties $(\mathrm{Z})$ are necessary for comparison between $\mathrm{U}-\mathrm{Pb}$ and ${ }^{40} \mathrm{Ar} /{ }^{39} \mathrm{Ar}$ age data. Uncertainties 
164 referred to in text are analytical uncertainties only unless otherwise noted. Linear interpolation is used to 165 calculate estimated ages and their associated uncertainties for events between dated horizons (e.g. K-Pg 166 boundary).

\section{Results}

4.1 Paleomagnetism - All but one (KJ08-59) of the 25 samples from the Kiowa core exhibited clear demagnetization behavior and could be characterized by least squares analysis (Table S1, Figure

171 S1). Initial AF demagnetization up to $100 \mathrm{mT}$ successfully isolated the ChRM for 19 of the 25 samples.

172 Samples KJ08-31B, KJ08-50A, KJ08-59A, KJ08-61A, KJ08-62A, and KJ08-63A were subjected to 173 additional thermal demagnetization as well. ChRM inclinations separate into two distinct groups with 174 means of $50.0^{\circ}$ (normal polarity) and $-35.4^{\circ}$ (reverse polarity; Figure S2A). This asymmetry between 175 normal and reversed mean inclinations is likely due to a present-day overprint (or drilling overprint) leaving reverse polarity samples (upward oriented inclinations) with shallower than expected ChRMs.

177 The resulting revised magnetostratigraphy for the Kiowa core significantly improves the stratigraphic 178 resolution of polarity reversals first identified by Hicks et al. (2003; Figure 2). Table 2 shows the new 179 stratigraphic constraints for the Chron C30n-C28n reversals (the very short Chron C30r is not recorded in the Kiowa core; Hicks et al., 2003). These geomagnetic reversals in the Kiowa core now have an average 181 stratigraphic uncertainty of \pm 0.76 meters $(= \pm 2.5$ feet; $<\sim 8 \mathrm{ky}$; stratigraphic levels here are reported in 182 English as well as metrics units for direct comparison to original drilling units of feet) which significantly 183 minimizes one important source of error in assigning ages and durations to geomagnetic chrons. Magnetostratigraphic results from outcrop sections exhibit a polarity record that can be easily

185 correlated to the adjacent Kiowa core record (Figures S1 \& S2B). Site statistics for those sites that pass 186 the Watson Test of randomness are listed in Table S2 (Watson, 1956). These sites pass the reversal test at 187 the $95 \%$ confidence interval (Tauxe et al., 2014; Figure S2C). The majority of these sites (64\%) were 188 based on sample directions that were all calculated by least squares analysis whereas the others included 189 sample directions calculated using a fisher mean or great circle (see Table S2 for details). The 
stratigraphically lowest section (My Lucky Number) exhibits reverse polarity at the base, interpreted here

191 to represent part of Chron C29r, and normal polarity towards the top, interpreted to be part of Chron

192 C29n. The stratigraphically higher Easy to Reach section exhibits normal polarity throughout which is

193 interpreted to represent part of Chron C29n. The uppermost Haas Ranch section exhibits a short zone of

194 reverse polarity near the base, interpreted to be Chron C28r, and normal polarity above, interpreted to be

195 Chron C28n. The top of the section is truncated disconformably by the D2 sequence of conglomerates

196 likely deposited during the early Eocene. By integrating these new magnetostratigraphic data with

197 differentially corrected GPS (dGPS) locations for the sample sites, we constructed a composite outcrop

198 record of polarity changes that is referenced to absolute elevation and can be easily correlated to the

199 record from the Kiowa core (Figure 2). Only C28r shows significant differences in thickness between the 200 core $(22.78-24.83 \mathrm{~m}=74.75-81.47 \mathrm{ft})$ and the outcrop $(<15.4 \mathrm{~m}=<50.5 \mathrm{ft})$ which could be related to (1)

201 the dynamic depositional processes associated with this active foreland basin, (2) a poor dGPS reading for

202 site DB0701 which was in a steep gully, or (3) a thick coarse channel sandstone that lies just above site

203 DB0701 (see Table S2), the base of which may represent a local disconformity.

4.2 U-Pb Geochronology - Volcanic ash horizons of the Denver Basin are volcanoclastic deposits that almost invariably contain xenocrystic zircon from sources as old as ca. $1.4 \mathrm{Ga}$. Analytical 207 precision of $0.1 \%(2 \sigma)$ or better on individual ${ }^{206} \mathrm{~Pb} /{ }^{238} \mathrm{U}$ dates allow isolation of the youngest population 208 of zircons from each ash in order to calculate statistically valid weighted mean dates. The latter can serve 209 as close estimates for the depositional age, once it can be demonstrated that dates from successive, closely 210 spaced, ash beds are mutually resolvable (outside analytical uncertainty) and obey their stratigraphic 211 order. The U-Pb age results and their detailed uncertainties are listed in Tables 1 and $\mathrm{S} 3$ and illustrated in 212 Figure S3. 
216 (Table 1; Figure S3). The weighted mean dates range from $66.304 \pm 0.029 \mathrm{Ma}$ to $64.520 \pm 0.029 \mathrm{Ma}$

217 (analytical $2 \sigma$ uncertainties only), are in the expected stratigraphic order, and all have 95\% confidence

218 intervals of less than $50 \mathrm{ky}$. By combining these new isotopic dates with the updated Kiowa core

219 magnetostratigraphy, it is possible to develop a high-resolution age model for the Core and assess the

220 existing absolute age calibrations for the GPTS (Figure 3B). Close proximity of the dated ash beds to the

221 polarity reversal boundaries and the K-Pg boundary in the Core allow their ages to be constrained with

222 minimal interpolation (e.g., sample KJ10-04 is only $36 \mathrm{~cm}=14.17$ in above the K-Pg boundary layer,

223 Figure 2). Interpolated ages for the Chron C30n/C29r, C29r/C29n, C29n/C28r, and C28r/C28n polarity

224 reversals as well as the K-Pg boundary are given in Table 2. The age progression of the five dated ashes

225 in the Kiowa core indicates somewhat higher average sediment accumulation rates in the Maastrichtian

226 and near the K-Pg boundary compared to that in the overlying Paleocene (Figure 3B).

4.2.2 Denver Basin outcrops - U-Pb zircon age determinations were also carried out on

three ash samples collected from exposed outcrops adjacent to the Kiowa core site in order to further test stratigraphic sections where the Chron C28n-C28r and C29n-C29r (respectively) polarity reversals are also recorded (Tables 1 and S3; Figure S3). At My Lucky Number, the stratigraphically lower sample (KJ07-54E) was collected from 17 meters (=56 feet) below the reversal and the upper one (KJ07-55B)

234 from between the reversed and normal polarity sites that define the reversal boundary in the section. As in 235 the core, the ages are in the expected stratigraphic order and have $95 \%$ confidence intervals of less than $23665 \mathrm{ky}$. The age for the Chron C29r-C29n boundary in the Kiowa core and in the My Lucky Number 237 outcrop section overlap within uncertainty showing excellent reproducibility despite $\sim 22 \mathrm{~km}$ distance 238 between them (Figure 4). The single sample (KJ04-56) from the Haas Ranch section also closely 239 corroborates the age of the C28n-C28r reversal in the Kiowa core (Figure 4). 

sequence has been identified precisely in outcrop records in the West Bijou Creek area based on palynology, as well as impact-derived proxies such as iridium and osmium concentrations, and shocked

244 quartz (Barclay, 2003; Nichols and Fleming, 2002; Zaiss et al., 2014). Several parallel trenches have been 245 excavated here to expose the K-Pg boundary stratigraphy for detailed study. The K-Pg boundary is 246 preserved in a sequence of interbedded gray mudstone and lignite with numerous interspersed thin 247 volcanic ash beds (Figure S4 and Table S4). A series of 6 successive and closely spaced volcanic ash 248 samples from one of these trenches called the Bowring Pit (Zaiss et al., 2014) were analyzed for U-Pb 249 zircon geochronology in order to determine a precise age of the K-Pg boundary and better constrain the 250 timing of associated biotic extinction and recovery (Figure S4; Table 1). The samples range in stratigraphy from $0.46 \mathrm{~m}(1.51 \mathrm{ft})$ below to $1.00 \mathrm{~m}(3.29 \mathrm{ft})$ above the K-Pg boundary layer and in calculated $\mathrm{U}-\mathrm{Pb}$ dates from $66.082 \pm 0.022 \mathrm{Ma}$ to $65.889 \pm 0.027 \mathrm{Ma}$, respectively. With only one exception, all ash samples yielded mutually resolvable dates consistent with the expected stratigraphic age progression (Table 1; Figure S4). Sample KJ12-01 (0.12 m = 0.38 ft above the boundary) produced a weighted mean date of $66.084 \pm 0.045 \mathrm{Ma}$, essentially identical to that of the underlying sample KJ08$157(0.46 \mathrm{~m}=1.51 \mathrm{ft}$ below the boundary $)$ and inconsistent with the observed upward age progression.

257 The former is suspected of containing a predominantly detrital (reworked) zircon population that is 258 demonstrably older than its true depositional age and thus excluded from the age model. results in an age of $66.040 \pm 0.021 \mathrm{Ma}$ which is indistinguishable from the interpolated K-Pg boundary 261 age from the Kiowa core results $(66.021 \pm 0.024 \mathrm{Ma})$. The estimated age of the K-Pg boundary from the 262 Bowring pit does not change significantly depending on which dates from the pit are included in the 263 interpolation. We prefer the $66.021 \pm 0.024 / 0.039 / 0.081 \mathrm{Ma}$ age for the K-Pg boundary because (1) 264 sample KJ10-04 in the Kiowa core is closest to the boundary thus requiring minimal interpolation and (2) 265 the Bowring Pit interpolated K-Pg boundary age $(66.021 \pm 0.024 \mathrm{Ma})$ is identical to the Kiowa age when 266 the stratigraphically highest (KJ04-70) and lowest (KJ08-157) ashes in the Bowring Pit are used as the 
bracketing points. The sediment accumulation rate within the Bowring pit appears to be relatively linear despite the short time interval covered. However, sediment accumulation rates in the pit are slower by an order of magnitude than the long-term accumulation rate calculated for the same part of the Kiowa core.

270 This could be due to calculating the accumulation rates over different thicknesses, however normally

271 sediment accumulation rates are faster when calculated over shorter stratigraphic intervals because they

272 average fewer hiatuses and paraconformities (Sadler, 1981). The discrepancy could also indicate a period 273 of especially slow sedimentation during the K-Pg boundary interval itself followed by a rapid rise in 274 accumulation immediately after the boundary. This would be consistent with the landscape instability 275 hypothesis proposed by Fastovsky et al. (2008) and is further corroborated here by the presence of what 276 we interpret to be an entirely reworked ash bed above the K-Pg boundary (sample KJ12-01).

\section{Discussion}

281 role in interpreting stratigraphic records of Earth history because polarity reversals are geologically rapid 282 and globally distributed making them ideal timelines for correlating between different depositional 283 environments and geographic locations. Accurate and precise calibration of the GPTS in absolute time is 284 critical for resolving rates of geological and biological processes which in turn help constrain the 285 underlying causes of those processes. Numerical calibration of the GPTS was traditionally carried out by 286 interpolation between a limited number of ${ }^{40} \mathrm{Ar} /{ }^{39} \mathrm{Ar}$ dates for volcanic ash deposits from superpositional 287 sequences with well-defined magnetostratigraphic records. More recently, the Neogene Period of the 288 GPTS has been calibrated using high-resolution astrochronological methods, however the application of 289 these approaches to pre-Neogene parts of the timescale is controversial given the uncertainties in relevant 290 astronomical parameters this far back in time (Laskar et al., 2004; Laskar et al., 2011a,b) and differing 291 interpretations of local cyclostratigraphic records (e.g. Dinarès-Turell et al., 2007; Hilgen et al., 2010; 292 Westerhold et al., 2008). Dinarès-Turell et al. (2007) reported a provisional astrochronology for the 
Paleocene based on an integrated magneto-, bio- and cyclo-stratigraphic records of the Zumaia section in

294 the Basque Basin of Spain (see also Dinarès-Turell et al., 2003). Westerhold et al. (2008) presented a

295 floating astrochronological calibration of the Paleocene GPTS by matching cyclic patterns in geochemical

296 proxies of climate change recovered from several Ocean Drilling Program (ODP) cores to the stable 405

297 ky eccentricity cycle (Laskar et al., 2004). This calibration was floating because of uncertainties

298 associated with the absolute age of the tie points (the Cretaceous-Tertiary boundary and the Paleocene-

299 Eocene Thermal Maximum) and a cyclostratigraphic gap in the overlying Eocene record. Hilgen et al.

300 (2010) suggested that the Paleocene had twenty five 405-ky cycles, rather than the 24 cycles that

301 Westerhold et al. (2008) had identified, and retuned the record accordingly. GTS2012 integrated the

302 Hilgen et al. (2010) astrochronological solution (see Table 28.2 of Gradstein et al., 2012) with an

303 independent radio-isotopically calibrated age model to derive their final "combined" age model for the

304 Paleocene. Westerhold et al. (2012) re-tuned the cyclostratigraphic records from several sections to the

305 updated LA2010 and LA2011 astronomical models (Laskar et al., 2011a; 2011b) and derived new age

306 estimates for the PETM and K-Pg boundary that are entirely independent of radioisotopic dates (see also

307 Husson et al., 2011). Most recently, Dinarès-Turell et al. (2014) re-examined several Danian records and

308 developed a new early Paleocene astrochronology that reportedly resolved previously disputed

309 discrepancies for this time interval. Although the discrepancies between these various calibrations of the

310 Paleocene timescale have reduced over time, there is still significant uncertainty about the best approach

311 for calibrating Paleogene time given the inherent uncertainties of astronomical solutions past $\sim 50 \mathrm{Ma}$

312 (Laskar et al., 2011a). Recent ${ }^{40} \mathrm{Ar} /{ }^{39} \mathrm{Ar}$ geochronology from the classic Hell Creek sections in Montana

313 provided an independent test of the late Cretaceous-early Paleocene GPTS calibrations. However ongoing

314 debate concerning the age of the Fish Canyon Tuff (FCT) sanidine standard that is used in ${ }^{40} \mathrm{Ar} /{ }^{39} \mathrm{Ar}$ date

315 calibration complicates their interpretation (Kuiper et al., 2008; Channell et al., 2010; Renne et al., 2010;

316 Rivera et al., 2011; Westerhold et al., 2012). Our new results from the Denver Basin provide a new test of

317 the various calibration methods for the pre-Neogene timescale by independently dating several Paleocene 
polarity chrons using high-precision $\mathrm{U}-\mathrm{Pb}$ geochronology within a tightly constrained magnetostratigraphy.

Figure $3 \mathrm{~B}$ shows the various proposed calibrations, ordered by publication date, for the early- to mid-Paleocene compared to the chronostratigraphic framework developed here from the Denver Basin.

322 The first and most important pattern in these comparisons is the obvious convergence in age calibration 323 solutions through time. Whereas earlier numerical calibrations of the GPTS widely diverged from each 324 other, the more recent ones are very similar to each other and converge with our new U-Pb based model 325 from Denver Basin. The differences between various calibrations for the Paleocene GPTS are now 326 typically less than 100,000 years (e.g., one short eccentricity cycle) which is a tribute to the progress made by the geochronological and astrochronological communities over the last 20 years. In order to measure the overall fit of our new age model to the previous calibrations, we calculated the average difference between the calibrated ages of all comparable polarity reversals (Figure 3C). The closest fits to our new age model are GPTS12 and the astrochronological calibration of Dinarès-Turell et al. (2014), with Hilgen et al. (2010) and Westerhold et al. (2008) Option 3 falling closely behind. The Sprain et al. (2015) ${ }^{40} \mathrm{Ar} /{ }^{39} \mathrm{Ar}$ model fits well also except for the $\mathrm{C} 29 \mathrm{r} / \mathrm{C} 30 \mathrm{n}$ and $\mathrm{C} 28 \mathrm{n} / \mathrm{C} 28 \mathrm{r}$ reversals where it diverges significantly from the Kiowa age model (as it does from GPTS). In particular, our data support a longer duration for Chron C29r ( $630 \pm 62 \mathrm{ky}$ ) compared to the Sprain et al. (2015; $345 \pm 38 \mathrm{ky})$, more consistent with GTS2012 (710 ky). Recent U-Pb age calibration of the Deccan flood basalts yielded a somewhat 336 longer duration of $736 \pm 37 \mathrm{ky}$ for Chron C29r (Schoene et al., 2015), however that outcrop sequence is 337 relatively discontinuous compared to the core records from the deep sea and Denver Basin. $(66.021 \pm 0.024 / 0.039 / 0.081 \mathrm{Ma})$ is very close to the ${ }^{40} \mathrm{Ar} /{ }^{39} \mathrm{Ar}$ derived age for the K-Pg boundary from 340 the Hell Creek sequence in Montana (66.043 \pm 0.086 Ma; fully propagated $2 \sigma$ uncertainty, Renne et al.,

341 2013; Sprain et al., 2015) suggesting these two independent isotopic chronometers are converging despite 342 ongoing debate regarding the true age of the Fish Canyon $\operatorname{Tuff}^{40} \mathrm{Ar} /{ }^{39} \mathrm{Ar}$ standard (Kuiper et al., 2008;

343 Westerhold et al., 2012) and the possible magma residence time for zircons (see review in Costa, 2008). 
Furthermore, the K-Pg boundary age from Denver Basin is almost identical to that from the astrochronological models (Dinarès-Turell et al., 2014) entirely independent of radioisotopic geochronology. As direct isotopic dating and astronomical calibration of Chron boundaries becomes more commonly applied, it will soon be possible to calibrate the entire late Cretaceous-Cenozoic GPTS without reference to marine magnetic anomaly profiles and the underlying assumption concerning rates of sea-

349 floor spreading. As direct scaling of superpositional sequences increasingly relies on high-resolution

350 isotope geochronology and calibrated astrochronology, the reduction of age and stratigraphic uncertainties 351 associated with datable samples will become even more important for attaining the highest possible temporal precision for the GPTS. Isotopic age uncertainties comparable to - or smaller than - the shortest recorded cyclostratigraphic periodicity are needed to fully assess the synchronicity of radioisotopic and astrochronological time scales (e.g., Machlus et al., 2015).

5.2 Biotic Implications - The high-resolution chronostratigraphic framework presented here has important implications for understanding rates of biotic extinction and recovery across the K-Pg boundary. For instance, a fern spore abundance anomaly ("fern spike") at the K-Pg boundary has been and at the West Bijou Creek locality (where fern spores reached 74\% abundance; Barclay, 2003; Nichols and Fleming, 2002). Such an increase in the relative abundance of fern spores directly superimposed on sedimentary evidence for a bolide impact at the K-Pg boundary has been observed in many terrestrial sites across the globe and has long been cited as strong evidence for widespread ecological turnover caused by events associated with the impact (see Vajda and Bercovici, 2014 for review). The new age model presented here allows for a precise temporal calibration of the fern spike. Using the median sediment accumulation rate of 142 years $/ \mathrm{cm}(=361$ years/inch) calculated from all possible pair-wise comparisons between the new $\mathrm{U}-\mathrm{Pb}$ dates reported here (including their $2 \sigma$ uncertainties) indicates that the $\sim 0.6 \mathrm{~cm}$ (= $0.24 \mathrm{inch}$ ) in stratigraphic thickness between the top of the K-Pg boundary layer and the peak in fern spore abundance (Barclay, 2003; Nichols and Fleming, 2002) represents $\sim 85$ years and the $\sim 6 \mathrm{~cm}(=2.36$ 
in) thick recovery interval after the initial peak in fern abundance lasted $\sim 850$ years, suggesting the entire

371 fern spike occurred over $\sim 1000$ years. However, sediment accumulation rates were probably highly

372 variable during the K-Pg boundary interval due to associated changes in landscape stability and the above

373 estimate does not account for that. Conservatively, the entire $6.6 \mathrm{~cm}$ ( $2.60 \mathrm{in})$ fern spike interval

374 represents between 0 and 71,000 years given that it is bracketed between the K-Pg boundary layer (66.021

$375 \pm 0.024 \mathrm{Ma})$ and sample KJ04-75 (65.993 $\pm 0.019 \mathrm{Ma})$, which lies $51.5 \mathrm{~cm}(20.27 \mathrm{in})$ above the K-Pg

376 boundary layer in the Bowring Pit.

377 In terms of vertebrates, the stratigraphically highest dinosaur specimens recovered in the Denver

378 Basin come from $4 \mathrm{~m}(13.1 \mathrm{ft})$ below the K-Pg boundary at the West Bijou Site (Barclay, 2003) and a

379 specimen of the Puercan 1 fossil mammal Protungulatum donnae was found $9 \mathrm{~m}(29.5 \mathrm{ft})$ above the K-Pg

380 boundary in the same area (Dahlberg et al., 2016). Using the same median sediment accumulation rate

381 described above, our data suggest that dinosaur extinction occurred within $\sim 57 \mathrm{ky}$ of the boundary layer

382 and initial Paleocene mammalian radiation started no more than $\sim 171 \mathrm{ky}$ after the boundary (= $228 \mathrm{ky}$ for

383 the interval between the uppermost dinosaur occurrence and the lowermost Cenozoic mammal

384 occurrence). This $16 \mathrm{~m}(52.5 \mathrm{ft})$ stratigraphic interval is bracketed by samples KJ08-53 $(65.801 \pm 0.038$

$385 \mathrm{Ma})$ and KJ10-09 (66.304 $\pm 0.029 \mathrm{Ma})$ in the Kiowa core, which suggests a conservative estimate of less

386 than $570 \mathrm{ky}$ for the interval between the extinction of the latest non-avian dinosaurs and the establishment

387 of the earliest Cenozoic mammal assemblages. Since dinosaur and mammal fossils are relatively

388 uncommon at the West Bijou Creek Site, these estimates represent maximum durations and these

389 durations may decrease with additional sampling. These represent some of the tightest temporal

390 constraints on biotic turnover across the K-Pg boundary for a continental system and suggest that both

391 extinction and initial recovery were geologically rapid in this setting.

392 The K-Pg boundary extinction is generally thought to be due to the catastrophic effects of the

393 Chicxulub bolide impact, the more prolonged environmental effects of the Deccan Traps volcanic

394 eruptions, or some combination of the two (Alvarez et al., 1980; Courtillot et al., 1986; Schulte et al.,

395 2010; Schoene et al., 2015). The age reported here for the K-Pg boundary layer in the Denver Basin 
$396(66.021 \pm 0.024 / 0.039 / 0.081 \mathrm{Ma})$ overlaps within $2 \sigma$ errors with the age of the K-Pg boundary layer in the

397 Hell Creek Formation of Montana based on ${ }^{40} \mathrm{Ar} /{ }^{39} \mathrm{Ar}$ geochronology (66.043 $\pm 0.086 \mathrm{Ma}$; Renne et al.,

398 2013; Sprain et al., 2015) and both of them are indistinguishable from the ${ }^{40} \mathrm{Ar} /{ }^{39} \mathrm{Ar}$ age of Chixculub

399 tektites $(66.038 \pm 0.098 \mathrm{Ma}$; Renne et al., 2013) providing strong support for the contemporaneous

400 emplacement of ejecta across western North America directly after the Chicxulub impact. Our data also

401 indicate that the fern spike occurred within $\sim 1000$ years of the ejecta layer, consistent with the timescale

402 for the carbon isotope anomaly in the Hell Creek Sections (Renne et al., 2013), and supportive of the

403 existence of landscape scale terrestrial ecosystem disruption due to effects of the impact. The observed

404 highest stratigraphic occurrence of dinosaurs and lowest Pu-1 mammals in the Denver basin are also

405 consistent with the impact playing an important role in ecosystem reorganization, but coincident

406 influences from the main phase of Deccan Trap volcanism cannot be ruled out given the sampling

407 resolution for these fossil groups.

408

409

6. Conclusions

A new U-Pb age model from a series of volcanic ash beds within a well-constrained latest

411 Cretaceous-Paleocene magnetobiostratigraphic framework in the Denver Basin provides an age of 66.021

$412 \pm 0.024 / 0.039 / 0.081 \mathrm{Ma}$ for the K-Pg boundary and allows precise temporal calibration for this part of the

413 Geomagnetic Polarity Timescale. These new results closely corroborate the most recently proposed

414 marine-based astronomical timescale for the same time interval and agree well with a recent ${ }^{40} \mathrm{Ar} /{ }^{39} \mathrm{Ar}$ age

415 model for the Hell Creek sequence in Montana but differ from that model in indicating a longer Chron

416 C29r, consistent with the astronomical solution. Analytical methods for temporal calibration of the

417 geological timescale $\left(\mathrm{U}-\mathrm{Pb},{ }^{40} \mathrm{Ar} /{ }^{39} \mathrm{Ar}\right.$, astrochronology) seem to be converging to within uncertainties of

418 each other, making the reduction of geological and stratigraphic uncertainties associated with datable

419 samples ever more important for improving future timescales. The new geochronological information also

420 provides key new constraints on the rates of biotic extinction and recovery across the K-Pg boundary. The

421 interval between the highest documented dinosaurs and the lowest sampled early Paleocene ("Puercan-1") 
mammals in the Denver Basin spans $228 \mathrm{ky}$ (and bracketed to be no longer than $-570 \mathrm{ky}$ ) in duration and initial recovery of plant ecosystems (as inferred by the end of the fern spike) occurred $\sim 1 \mathrm{ky}$ (and no more 424 than $71 \mathrm{ky})$ after the K-Pg boundary layer.

\section{Acknowledgements}

427 Property access to the West Bijou and My Lucky Number sites was provided by the Plains Conservation 428 Center; to the Easy to Reach section by Toby Pippin; to the Hass Ranch section by Robert and Dale Haas. 429 The project was supported by NSF grants EAR 9805474 to KRJ and R. Raynolds, EAR 0643158 to SAB, 430 EAR 0642291 to WCC and EAR 0642838 to KRJ. We thank R. Barclay, T. Barnum, R. Dodds, B. Ellis, 431 I. Miller, R. Raynolds and K. Tsukui, for help with field work, lab work and helpful discussions. Thanks to J. Crowley for preliminary U-Pb analyses from the Bowring Pit at MIT.

433

434

\section{References Cited}

Alvarez, L.W., Alvarez, W., Asaro, F., Michel, H.V., 1980. Extraterrestrial cause for the CretaceousTertiary extinction. Science 208, 1095-1108. doi:10.1126/science.208.4448.1095

Barclay, R.S., 2003. Stratigraphy and megaflora of a K-T boundary section in the eastern Denver Basin, Colorado. Rocky Mt. Geol. 38, 45-71. doi:10.2113/gsrocky.38.1.45

Bowring, S.A., Schoene, B., Crowley, J.L., Ramezani, J., Condon, D.J., 2006. High-precision U-Pb zircon geochronology and the stratigraphic record: progress and promise, in: Olszewski, T.D. (Ed.), Geochronology: Emerging Opportunities. The Paleontological Society Papers, Vol. 12, p. $25-45$.

Cande, S.C., Kent, D.V., 1995. Revised calibration of the geomagnetic polarity time scale for the Late Cretaceous and Cenozoic. J. Geophys. Res. 100, 6093-6095.

Cande, S.C., Kent, D.V., 1992. A new geomagnetic polarity time scale for the Late Cretaceous and Cenozoic. J. Geophys. Res. 97, 647-657. 
Carpenter, K., Young, D.B., 2002. Late Cretaceous dinosaurs from the Denver Basin, Colorado. Rocky Mt. Geol. 37, 237-254.

Channell, J.E.T., Hodell, D.A., Singer, B.S., Xuan, C., 2010. Reconciling astrochronological and ${ }^{40} \mathrm{Ar} /$ ${ }^{39} \mathrm{Ar}$ ages for the Matuyama-Brunhes boundary and late Matuyama Chron, Geochem. Geophys. Geosystems 11, n/a-n/a. doi:10.1029/2010GC003203

Condon, D.J., Schoene, B., McLean, N.M., Bowring, S.A., Parrish, R.R., 2015. Metrology and traceability of U-Pb isotope dilution geochronology (EARTHTIME Tracer Calibration Part I). Geochimica Et Cosmochimica Acta 164, 464-480.

Costa, F., 2008. Residence times of silicic magmas associated with calderas, in: Gottsmann, J., Marti, J. (Eds.), Developments in Volcanology Volume 10. Elsevier, pp. 1-55.

Courtillot, V., Besse, J., Vandamme, D., Montigny, R., Jaeger, J.-J., Cappetta, H., 1986. Deccan flood basalts at the Cretaceous/Tertiary boundary? Earth Planet. Sci. Lett. 80, 361-374. doi:10.1016/0012-821X(86)90118-4

Dahlberg, E.L., Eberle, J.J., Sertich, J.J.W., Miller, I.M., 2016. A new earliest Paleocene (Puercan) mammalian fauna from Colorado's Denver Basin, U.S.A. Rocky Mt. Geol. 51, 1-22. doi:10.2113/gsrocky.51.1.1

Dinarès-Turell, J., Baceta, J.I., Pujalte, V., Orue-Etxebarria, X., Bernaola, G., Lorito, S., 2003. Untangling the Palaeocene climatic rhythm: an astronomically calibrated Early Palaeocene magnetostratigraphy and biostratigraphy at Zumaia (Basque basin, northern Spain). Earth Planet. Sci. Lett. 216, 483-500.

Dinarès-Turell, J., Baceta, J.I., Bernaola, G., Orue-Etxebarria, X., Pujalte, V., 2007. Closing the MidPalaeocene gap: Toward a complete astronomically tuned Palaeocene Epoch and Selandian and Thanetian GSSPs at Zumaia (Basque Basin, W Pyrenees). Earth Planet. Sci. Lett. 262, 450-467. doi:10.1016/j.eps1.2007.08.008

Dinarès-Turell, J., Westerhold, T., Pujalte, V., Röhl, U., Kroon, D., 2014. Astronomical calibration of the Danian stage (Early Paleocene) revisited: Settling chronologies of sedimentary records across the 
Atlantic and Pacific Oceans. Earth Planet. Sci. Lett. 405, 119-131. doi:10.1016/j.eps1.2014.08.027

Fastovsky, D.E., Sheehan, P.M., Isbell, J.L., Grandpre, R. 2008, Anomalous, temporary terrestrial sedimentary environments following Cretaceous-Tertiary ecosystem disruptions: North America, Asia, and Europe. Geol. Soc. Am. Abstr. Programs 40, 322.

Gradstein, F.M., Ogg, J.G., Schmitz, M., Ogg, G., 2012. The Geologic Time Scale 2012. Elsevier, Oxford.

Gradstein, F.M., Ogg, J.G., Smith, A.G. (Eds.), 2004. Geological Time Scale 2004. Cambridge University Press, Cambridge, UK.

Hicks, J.F., Johnson, K.R., Obradovich, J.D., Miggins, D.P., Tauxe, L., 2003. Magnetostratigraphy of Upper Cretaceous (Maastrichtian) to lower Eocene strata of the Denver Basin, Colorado, Paleontology and stratigraphy of Laramide strata in the Denver Basin; Part II; Rocky Mt. Geol., $38,1-27$.

Hilgen, F.J., Kuiper, K.F., Lourens, L.J., 2010. Evaluation of the astronomical time scale for the Paleocene and earliest Eocene. Earth Planet. Sci. Lett. 300, 139-151. 10.1016/j.eps1.2010.09.044

Hinnov, L.A., Hilgen, F.J., 2012. Chapter 4 - Cyclostratigraphy and Astrochronology, in: Gradstein, F.M., Schmitz, J.G.O.D., Ogg, G.M. (Eds.), The Geologic Time Scale. Elsevier, Boston, pp. 63-83.

Hoke, G.D., Schmitz, M.D., Bowring, S.A., 2014. An ultrasonic method for isolating nonclay components from clay-rich material. Geochem. Geophys. Geosystems 15, 492-498.

Husson, D., Galbrun, B., Laskar, J., Hinnov, L.A., Thibault, N., Gardin, S., Locklair, R.E., 2011. Astronomical calibration of the Maastrichtian (Late Cretaceous). Earth Planet. Sci. Lett. 305, 328-340. doi:10.1016/j.eps1.2011.03.008

Johnson, K.R., Raynolds, R.G., Reynolds, M.L., 2003. Paleontology and stratigraphy of Laramide strata in the Denver Basin (Part II), Rocky Mt. Geol. 38, 181p.

Kirschvink, J.L., 1980. The least-squares line and plane and the analysis of paleomagnetic data. Geophys. J. R. Astron. Soc. 62, 743-746. 
Kuiper, K.F., Deino, A., Hilgen, F.J., Krijgsman, W., Renne, P.R., Wijbrans, J.R., 2008. Synchronizing rock clocks of Earth history. Science 320, 500-504.

Laskar, J., Fienga, A., Gastineau, M., Manche, H., 2011a. La2010: a new orbital solution for the longterm motion of the Earth. Astron. Astrophys. 532, A89. doi:10.1051/0004-6361/201116836

Laskar, J., Gastineau, M., Delisle, J.-B., Farrés, A., Fienga, A., 2011b. Strong chaos induced by close encounters with Ceres and Vesta. Astron. Astrophys. 532, L4.

Laskar, J., Robutel, P., Joutel, F., Gastineau, M., Correia, A.C.M., Levrard, B., 2004. A long-term numerical solution for the insolation quantities of the Earth. Astron. Astrophys. 428, 261-285. doi:10.1051/0004-6361:20041335

Machlus, M.L., Ramezani, J., Bowring, S.A., Hemming, S.R., Tsukui, K., Clyde, W.C., 2015. A strategy for cross-calibrating $\mathrm{U}-\mathrm{Pb}$ chronology and astrochronology of sedimentary sequences: An example from the Green River Formation, Wyoming, USA. Earth Planet. Sci. Lett. 413, 70-78.

Mattinson, J.M., 2005. Zircon U-Pb chemical abrasion (“CA-TIMS”) method: combined annealing and multi-step partial dissolution analysis for improved precision and accuracy of zircon ages. Chem. Geol. 220, 47-66.

McFadden, P.L., McElhinney, M.W., 1988. The combined analysis of remagnetization circles and direct observations in palaeomagnetism. Earth Planet. Sci. Lett. 87, 161-172.

McLean, N.M., Condon, D.J., Schoene, B., Bowring, S.A., 2015. Evaluating uncertainties in the calibration of isotopic reference materials and multi-element isotopic tracers (EARTHTIME Tracer Calibration Part II). Geochimica Et Cosmochimica Acta 164, 481-501.

Nichols, D.J., Fleming, R.F., 2002. Palynology and palynostratigraphy of Maastrichtian, Paleocene, and Eocene strata in the Denver Basin, Colorado. Rocky Mt. Geol. 37, 135-163.

Nichols, D.J., Johnson, K.R., 2008. Plants and the K-T Boundary. Cambridge University Press.

Ramezani, J., Hoke, G.D., Fastovsky, D.E., Bowring, S.A., Therrien, F., Dworkin, S.I., Atchley, S.C., Nordt, L.C., 2011. High-precision U-Pb zircon geochronology of the Late Triassic Chinle 
Formation, Petrified Forest National Park (Arizona, USA): Temporal constraints on the early evolution of dinosaurs. Geol. Soc. Am. Bull. 123, 2142-2159.

Raynolds, R.G.H., Johnson, K.R., Arnold, L.R., Farnham, T.M., Fleming, R.F., Hicks, J.F., Kelley, S.A., Lapey, L.A., Nichols, D.J., Obradovich, J.D., Wilson, M.D., 2001. The Kiowa core, a continuous drill core through the Denver Basin bedrock aquifers at Kiowa, Elbert County, Colorado; USGS Open-File Report. No. 2001-185. http://pubs.er.usgs.gov/publication/ofr01185.

Raynolds, R.G., 2002. Upper Cretaceous and Tertiary stratigraphy of the Denver Basin, Colorado. Rocky Mt. Geol. 37, 111-134. doi:10.2113/gsrocky.37.2.111.

Renne, P.R., Deino, A.L., Hilgen, F.J., Kuiper, K.F., Mark, D.F., Mitchell, W.S., Morgan, L.E., Mundil, R., Smit, J., 2013. Time scales of critical events around the Cretaceous-Paleogene boundary. Science 339, 684-687.

Renne, P.R., Mundil, R., Balco, G., Min, K., Ludwig, K.R., 2010. Joint determination of 40K decay constants and 40Ar/40K for the Fish Canyon sanidine standard, and improved accuracy for 40Ar/39Ar geochronology. Geochim. Cosmochim. Acta 74, 5349-5367. doi:10.1016/j.gca.2010.06.017

Rivera, T.A., Storey, M., Zeeden, C., Hilgen, F.J., Kuiper, K., 2011. A refined astronomically calibrated ${ }^{40} \mathrm{Ar} /{ }^{39} \mathrm{Ar}$ age for Fish Canyon sanidine. Earth Planet. Sci. Lett. 311, 420-426.

Sadler, P.M., 1981. Sediment accumulation rates and the completeness of stratigraphic sections. J. Geol. $89,569-584$.

Schoene, B., Samperton, K.M., Eddy, M.P., Keller, G., Adatte, T., Bowring, S.A., Khadri, S.F.R., Gertsch, B., 2015. U-Pb geochronology of the Deccan Traps and relation to the end-Cretaceous mass extinction. Science 347, 182-184. doi:10.1126/science.aaa0118

Schulte, P., Alegret, L., Arenillas, I., Arz, J.A., Barton, P.J., Bown, P.R., Bralower, T.J., Christeson, G.L., Claeys, P., Cockell, C.S., Collins, G.S., Deutsch, A., Goldin, T.J., Goto, K., Grajales-Nishimura, J.M., Grieve, R.A.F., Gulick, S.P.S., Johnson, K.R., Kiessling, W., Koeberl, C., Kring, D.A., MacLeod, K.G., Matsui, T., Melosh, J., Montanari, A., Morgan, J.V., Neal, C.R., Nichols, D.J., 
568

Norris, R.D., Pierazzo, E., Ravizza, G., Rebolledo-Vieyra, M., Reimold, W.U., Robin, E., Salge, T., Speijer, R.P., Sweet, A.R., Urrutia-Fucugauchi, J., Vajda, V., Whalen, M.T., Willumsen, P.S., 2010. The Chicxulub asteroid impact and mass extinction at the Cretaceous-Paleogene boundary. Science 327, 1214-1218. doi:10.1126/science.1177265

Sprain, C.J., Renne, P.R., Wilson, G.P., Clemens, W.A., 2015. High-resolution chronostratigraphy of the terrestrial Cretaceous-Paleogene transition and recovery interval in the Hell Creek region, Montana. Geol. Soc. Am. Bull. 127, 393-409. doi:10.1130/B31076.1

Tauxe, L., Banerjee, S.K., Butler, R.F., Van der Voo, R., 2014. Essentials of Paleomagnetism, 3rd Web Edition. ed.

Vajda, V., Bercovici, A., 2014. The global vegetation pattern across the Cretaceous-Paleogene mass extinction interval: A template for other extinction events. Glob. Planet. Change 122, 29-49. doi:10.1016/j.gloplacha.2014.07.014

Watson, G.S., 1956. A test for randomness of directions. Mon. Not. R. Astron. Soc. Geophys. Suppl. 7, $160-161$.

Westerhold, T., Röhl, U., Laskar, J., 2012. Time scale controversy: Accurate orbital calibration of the early Paleogene. Geochem. Geophys. Geosystems 13. doi:10.1029/2012GC004096

Westerhold, T., Röhl, U., Raffi, I., Fornaciari, E., Monechi, S., Reale, V., Bowles, J., Evans, H.F., 2008. Astronomical calibration of the Paleocene time. Palaeogeogr. Palaeoclimatol. Palaeoecol. 257, $377-403$.

Zaiss, J., Ravizza, G., Goderis, S., Sauvage, J., Claeys, P., Johnson, K., 2014. A complete Os excursion across a terrestrial Cretaceous-Paleogene boundary at the West Bijou Site, Colorado, with evidence for recent open system behavior. Chem. Geol. 385, 7-16. doi:10.1016/j.chemgeo.2014.07.010 
Figure Captions

580 Figure 1 - Geological map of the Denver Basin showing trace of K-Pg boundary (dark gray line) and

581 location of Kiowa core drill site and surface outcrop sites discussed in text (adapted from Raynolds, 582 2002).

Figure 2 - Fence Diagram showing the stratigraphic framework for this study. Kiowa core information is on left showing chronostratigraphy, lithostratigraphy ("lith"), pollen biostratigraphy (Nichols and Fleming, 2002), magnetostratigraphic data ("inclination" of characteristic remanent magnetization), and proposed correlation to the Geomagnetic Polarity Timescale (GPTS; Gradstein et al., 2012). Outcrop sections are on the right showing magnetostratigraphic information (VGP lat = latitude of virtual geomagnetic pole) and proposed correlation to the GPTS and Kiowa core. Map at upper right shows the location of the Kiowa core and outcrop sections. Vertical axis for Kiowa core graph is depth below

591 surface. Vertical axis for Haas Ranch, Easy to Reach, and My Lucky Number sections is elevation as 592 determined by differential GPS. Vertical axis for West Bijou Creek is stratigraphic level above/below the 593 K-Pg boundary layer. New paleomagnetic data from this study are shown as black points and previously 594 published data (Hicks et al., 2003) are shown as gray points (each representing a mean of 3-4 samples).

595 Asterisks show stratigraphic positions of volcanic ashes that were dated in this study using U-Pb

596 geochronology (see Table 1 and Figure 4). Stratigraphic scales are shown in feet (as well as meters)

597 because that is the original drilling depth unit for the Kiowa core.

599 Figure 3 - (A) Magnetostratigraphy of Kiowa core (new data in black, data from Hicks et al., 2003 in 600 gray, see Figure 2) with comparison of Denver Basin U-Pb age model (red circles) to previously 601 published age models (black squares). Size of data point encompasses the error bars for stratigraphic 
602 uncertainty (y axis) and 95\% confidence interval on age (x axis). New Denver Basin U-Pb age model (red 603 circles) plots age and stratigraphic positions for Kiowa core volcanic ash beds analyzed in this study 604 whereas previously published age models (black squares) show estimated ages for relevant GPTS tie 605 points (K-Pg and Chron boundaries). (C) Average difference in age (ky) of tie points (K-Pg and Chron 606 boundaries) between Denver Basin age model and previously published age models. Stratigraphic scale is 607 shown in feet because that is the original drilling depth unit for the Kiowa core.

608

609 Figure 4 - Comparison of the integrated geochronology for the (A) Chron C28r-28n reversal, (B) Chron 610 C29r-C29n reversal and (C) K-Pg boundary in the outcrop record (right) and Kiowa core record (left) of 611 the Denver Basin. Dark blue paleomagnetic data points are from this study and grey ones are from Hicks 612 et al. (2003). Red lines indicate position of volcanic ash beds that have been dated using high precision U$613 \mathrm{~Pb}$ geochronology. The polarity reversals and K-Pg boundary are calibrated to be the same age (within 614 error) in both outcrop and Core records. Stratigraphic scales are shown in feet because that is the original 615 drilling depth unit for the Kiowa core. 
Figure 1 (Low Resolution)

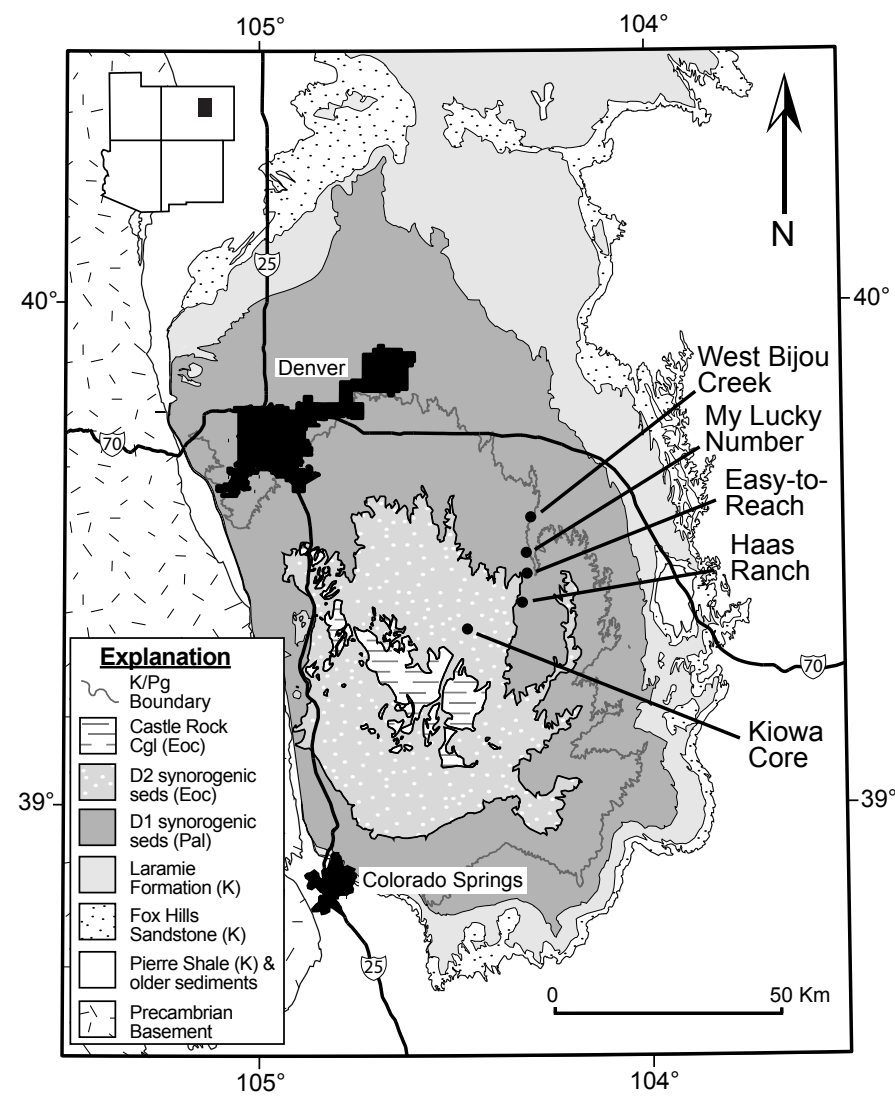




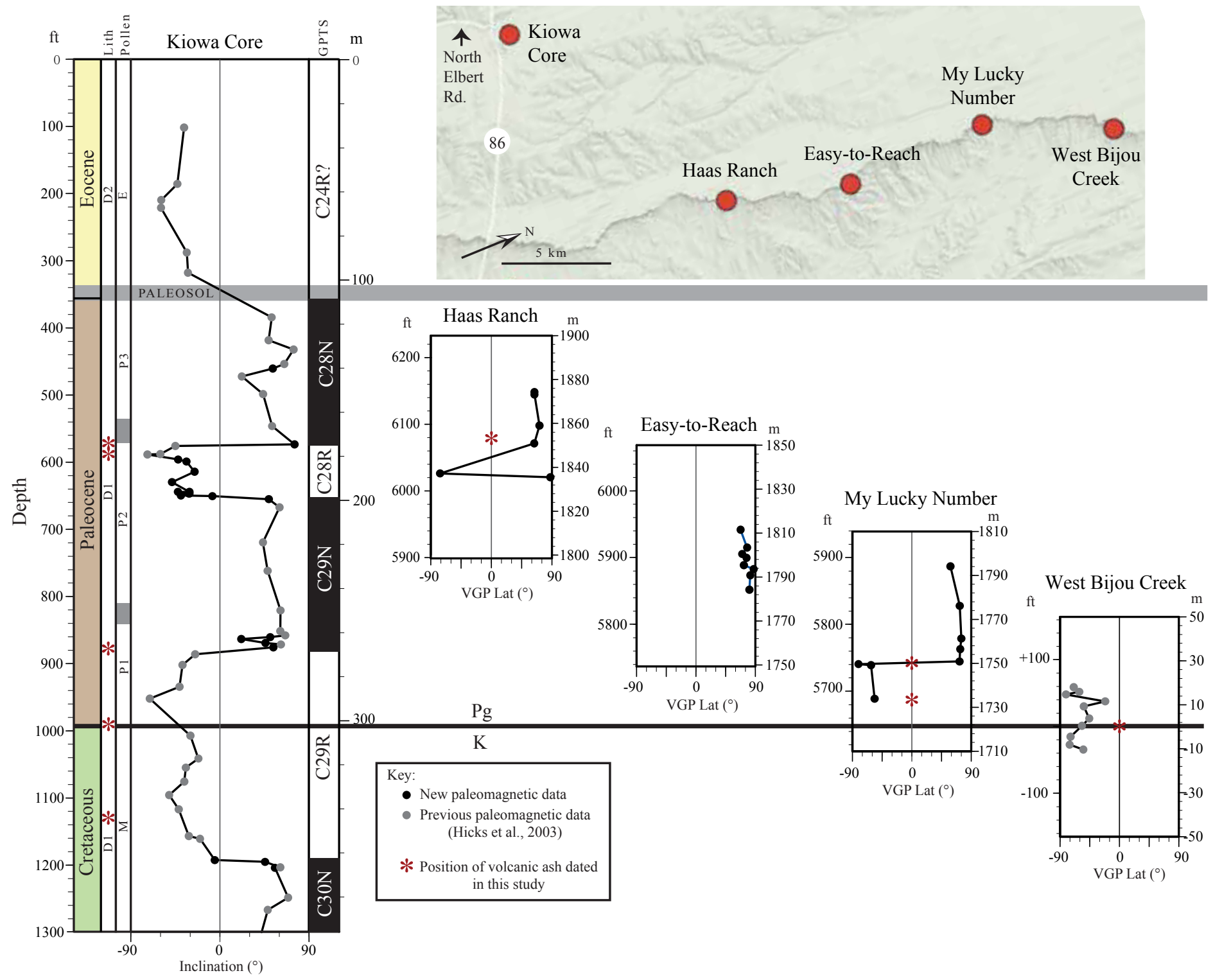




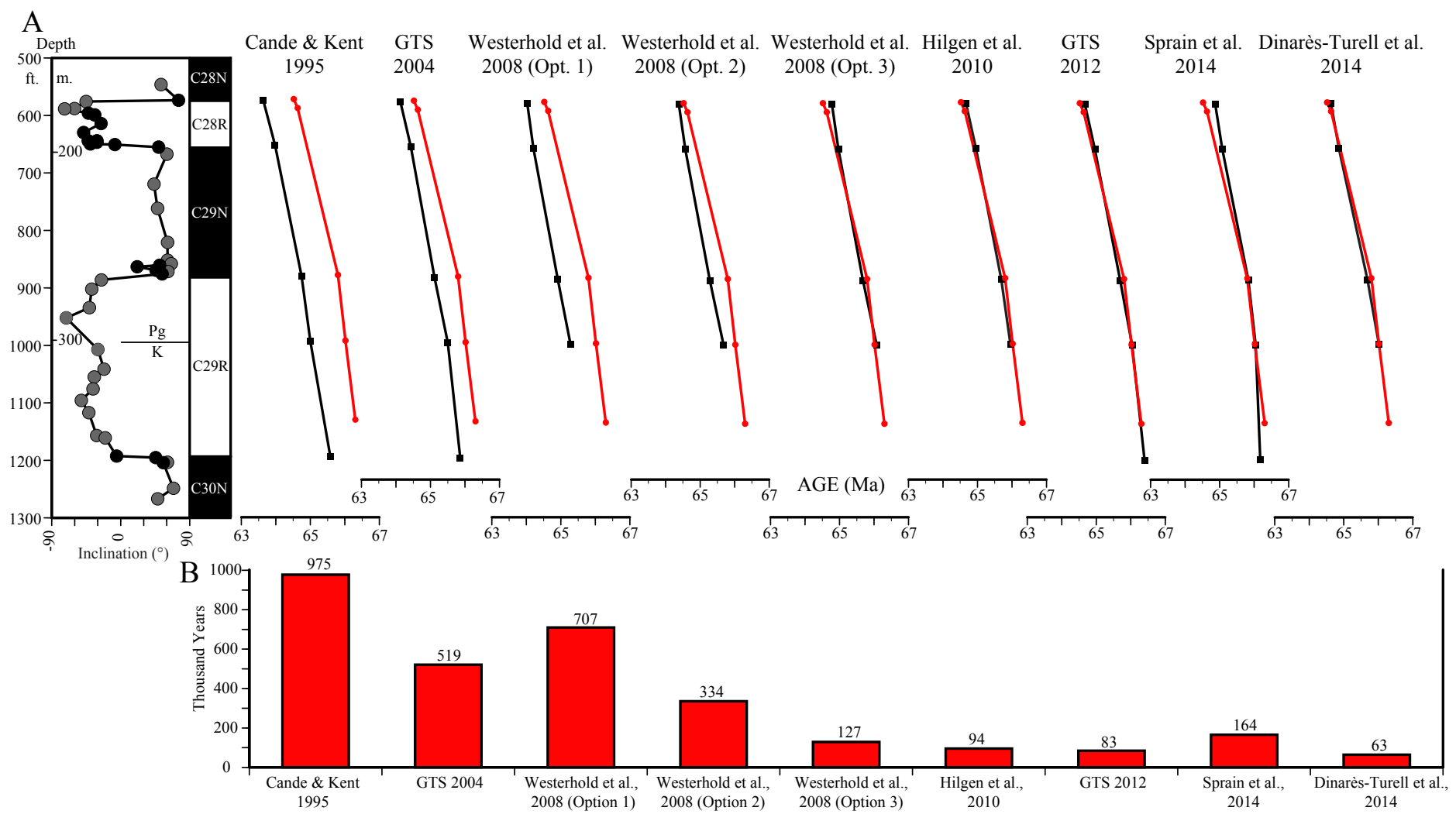


Figure 4 (Low Resolution)
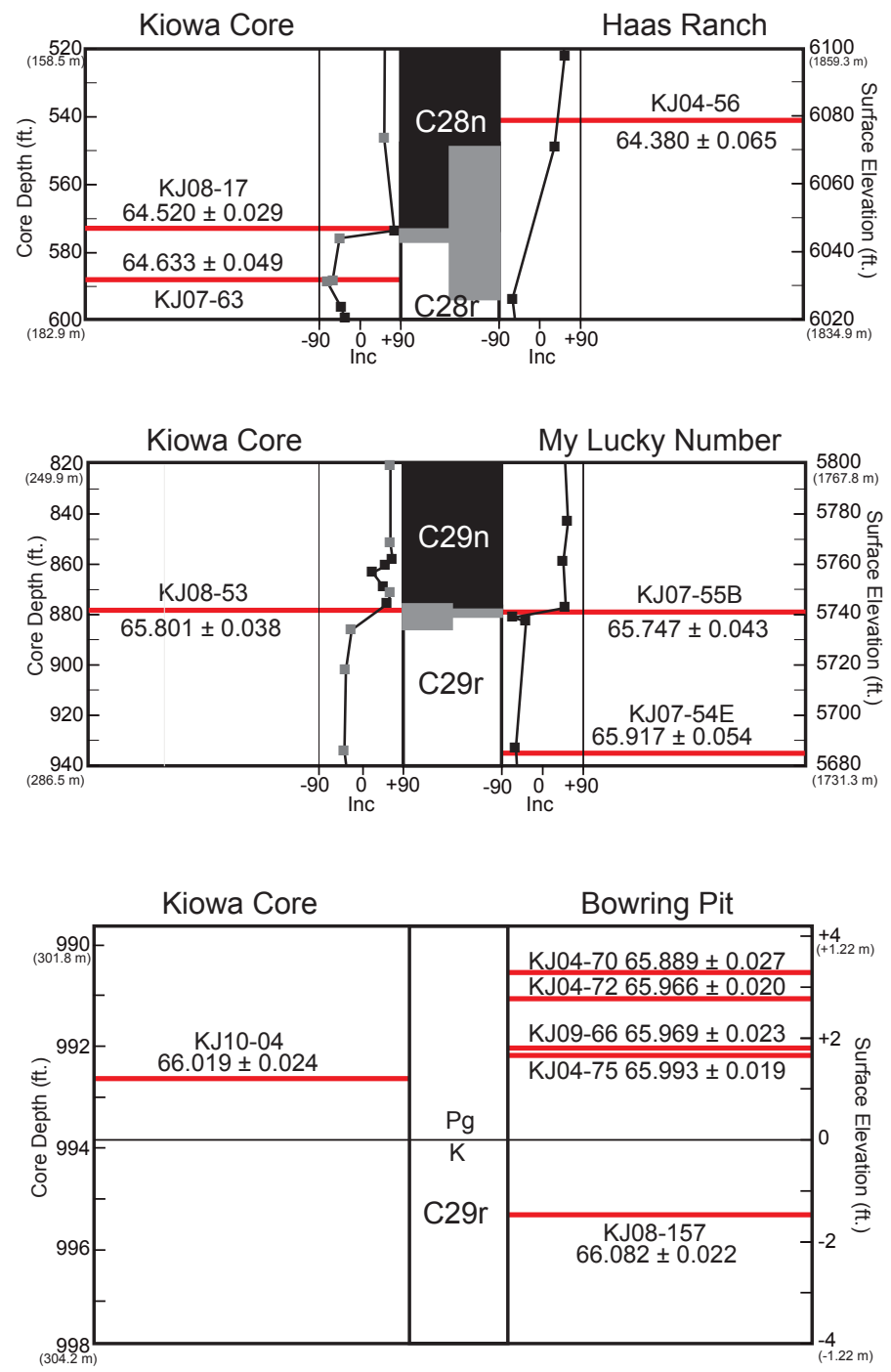
Table 1 - Summary of calculated $\mathrm{U}-\mathrm{Pb}$ ages and their uncertainties.

\begin{tabular}{|c|c|c|c|c|c|c|c|c|c|c|c|c|}
\hline \multirow[t]{2}{*}{ Sample } & \multirow[t]{2}{*}{ Location } & \multirow[t]{2}{*}{ Latitude } & \multirow[t]{2}{*}{ Longitude } & \multirow{2}{*}{$\begin{array}{c}\text { Elev/Level/Depth } \\
\text { (ft.) }\end{array}$} & \multirow{2}{*}{$\begin{array}{c}\text { Elev/Level/Depth } \\
(\mathrm{m})\end{array}$} & \multirow[t]{2}{*}{${ }^{206} \mathrm{~Pb} /{ }^{238} \mathrm{U}$ age } & \multicolumn{3}{|c|}{ Uncertainty $(2 \sigma)$} & \multirow[t]{2}{*}{ MSWD } & \multirow[t]{2}{*}{$\mathbf{n}$} & \multirow[t]{2}{*}{ \# } \\
\hline & & & & & & & $x$ & $\mathbf{Y}$ & $\mathrm{z}$ & & & \\
\hline KJ04-56 & Haas Ranch & 39.41198 & -104.34049 & 6079.28 & 1852.97 & 64.380 & 0.065 & 0.074 & 0.100 & 0.49 & 5 & 8 \\
\hline KJ07-55B & My Lucky No. & 39.52267 & -104.32809 & 5741.98 & 1750.15 & 65.747 & 0.043 & 0.054 & 0.088 & 0.25 & 5 & 8 \\
\hline KJ07-54E & My Lucky No. & 39.52366 & -104.32127 & 5685.77 & 1733.02 & 65.917 & 0.054 & 0.064 & 0.095 & 0.17 & 5 & 11 \\
\hline KJ04-70 & Bowring Pit & 39.57059 & -104.30306 & 3.29 & 1.00 & 65.889 & 0.027 & 0.044 & 0.083 & 1.10 & 11 & 14 \\
\hline KJ04-72 & Bowring Pit & $"$ & $"$ & 2.83 & 0.86 & 65.966 & 0.020 & 0.039 & 0.080 & 0.82 & 13 & 13 \\
\hline KJ09-66 & Bowring Pit & " & " & 1.77 & 0.54 & 65.969 & 0.023 & 0.039 & 0.081 & 0.67 & 8 & 11 \\
\hline KJ04-75 & Bowring Pit & $"$ & $"$ & 1.69 & 0.52 & 65.993 & 0.019 & 0.037 & 0.079 & 1.30 & 14 & 21 \\
\hline KJ12-01 & Bowring Pit & $"$ & $"$ & 0.38 & 0.12 & 66.084 & 0.045 & 0.064 & 0.095 & 1.60 & 9 & 11 \\
\hline KJ08-157 & Bowring Pit & $"$ & $"$ & -1.51 & -0.46 & 66.082 & 0.022 & 0.037 & 0.080 & 0.78 & 12 & 14 \\
\hline KJ08-17 & Kiowa core & 39.35242 & -104.46642 & 572.58 & 174.52 & 64.520 & 0.029 & 0.043 & 0.081 & 0.76 & 8 & 12 \\
\hline KJ07-63 & Kiowa core & $"$ & $"$ & 588.13 & 179.26 & 64.633 & 0.049 & 0.063 & 0.094 & 0.57 & 6 & 8 \\
\hline KJ08-53 & Kiowa core & $"$ & $"$ & 878.40 & 267.74 & 65.801 & 0.038 & 0.054 & 0.088 & 0.93 & 8 & 11 \\
\hline KJ10-04 & Kiowa core & $"$ & $"$ & 992.66 & 302.56 & 66.019 & 0.024 & 0.038 & 0.080 & 0.94 & 5 & 9 \\
\hline KJ10-09 & Kiowa core & $"$ & $"$ & 1130.25 & 344.50 & 66.304 & 0.029 & 0.044 & 0.083 & 0.58 & 6 & 8 \\
\hline
\end{tabular}

Notes: Latitude/Longitude: Relative to WGS 84 datum; Elev/Level/Depth (ft.): Elevation above sea level for outcrop sections (Haas Ranch and My Lucky No.), stratigraphic level relative to the top of the K/Pg boundary clay layer for Bowring Pit, and depth below suface for Kiowa Core; X: internal (analytical) uncertainty in the absence of all external or systematic errors; Y: incorporates the U-Pb tracer calibration error; $Z$ : includes $\mathrm{X}$ and $\mathrm{Y}$, as well as the uranium decay constant errors; MSWD: mean square of weighted deviates; $n$ : number of analyses from the total \# included in the calculated weighted mean date. 
Table 2 - Revised depth and ages of boundaries between Chrons C28r through C30n in the Kiowa Core.

\begin{tabular}{lrrrrrr} 
Chron Boundary & Depth $(\mathbf{f t})$ & $\boldsymbol{+} / \mathbf{-}(\mathbf{f t})$ & Depth $(\mathbf{m})$ & $\boldsymbol{+} /-\mathbf{( m )}$ & Age (Ma) & $\boldsymbol{+} /-(\mathbf{m y})$ \\
\hline C28r/C28n & 574.67 & 1.13 & 175.16 & 0.34 & 64.535 & 0.040 \\
C29n/C28r & 652.78 & 2.23 & 198.97 & 0.68 & 64.893 & 0.056 \\
C29r/C29n & 880.82 & 5.19 & 268.47 & 1.58 & 65.806 & 0.048 \\
K/Pg Boundary & 993.85 & 0.00 & 302.93 & 0.00 & 66.021 & 0.024 \\
C30n/C29r & 1193.85 & 1.35 & 363.89 & 0.41 & 66.436 & 0.039 \\
\hline
\end{tabular}

Notes: Ma - Million years ago; +/- uncertainty in age represents the fully propagated $95 \%$ confidence interval including stratigraphic error. 